\title{
Exposure Daily Dose
}

National Cancer Institute

\section{Source}

National Cancer Institute. Exposure Daily Dose. NCI Thesaurus. Code C83278.

The total amount of substance the subject is exposed to daily. 